\title{
Effects of thermal effluents from a power station on bacteria and heterotrophic nanoflagellates in coastal waters
}

\author{
Dong H. Choi ${ }^{1}$, Jong S. Park ${ }^{1}$, Chung Y. Hwang ${ }^{1}$, Sung H. Huh ${ }^{2}$, Byung C. Cho ${ }^{1, *}$ \\ ${ }^{1}$ School of Earth and Environmental Sciences and Research Institute of Oceanography, Seoul National University, \\ Seoul 151-742, Korea \\ ${ }^{2}$ Department of Oceanography, Pukyong National University, Pusan 608-737, Korea
}

\begin{abstract}
To investigate effects of thermal effluents from a coastal power station on bacteria and heterotrophic nanoflagellates (HNF) in adjacent coastal waters, surface distributions of bacteria and HNF and interrelations between microbial and environmental variables were studied in November 1998 and July, August and November 1999 near Hadong Power Station, Korea. In addition, manipulation experiments with treatments of high temperature $\left(40^{\circ} \mathrm{C}\right.$; temperature in the cooling system of the power station) and additions of hypochlorite and dilution experiments of thermal effluents with intake seawaters were carried out. Water temperature in the discharge-channel was always 5 to $10^{\circ} \mathrm{C}$ higher than the ambient temperature, but bacterial production, HNF abundance and grazing rates on bacteria, as well as chlorophyll a concentrations, were always lower there and increased with distance from the power station. Manipulation experiments showed that addition of hypochlorite had much more deleterious effects on bacteria and HNF (95 to $98 \%$ inhibition of bacterial production and 25 to $45 \%$ decrease in HNF abundance at $0.13 \mathrm{ppm}$ of residual chlorine) than high temperature (9 to $39 \%$ inhibition of bacterial production but no inhibition of HNF abundance at $40^{\circ} \mathrm{C}$ ). Dilutions of thermal effluents from the outlet and condenser tube with intake seawater would bring $<0.03 \mathrm{ppm}$ of residual chlorine, but inhibitory effects of thermal effluents on bacterial production and HNF grazing activity (23 to $69 \%$ inhibition of bacterial production and 31 to $36 \%$ inhibition of HNF grazing) were shown, indicating inhibitory potential of chlorination by-products in the discharged water on coastal microbes. Analyses of horizontal distributions of microbial variables, manipulation and dilution experiments gave consistently similar results of inhibitory effects of thermal effluents on bacteria and HNF. Our work suggests that a microbial ecological approach is useful in estimating influences of thermal pollution on microbes in aquatic environments.
\end{abstract}

KEY WORDS: Thermal effluents $\cdot$ Chlorination $\cdot$ Bacteria $\cdot$ Heterotrophic nanoflagellates

\section{INTRODUCTION}

Coastal power stations generally use seawater as cooling water and thus release seawater with elevated temperature into nearshore environments. In addition, antifouling chemicals are injected into intake seawater to prevent the growth of fouling organisms on the sur-

*Corresponding author. E-mail: bccho@plaza.snu.ac.kr face of the cooling systems. Chlorination of seawater is mostly employed by coastal power stations and thereby causes formation of chlorination by-products which might potentially inhibit microbes (Langford 1990). During the passage through cooling systems, intake seawater containing natural microbes is thus exposed to both high temperature (rarely exceeding $40^{\circ} \mathrm{C}$ ) and antifouling chemicals for a short time (e.g. about 10 to $30 \mathrm{~min}$ ). At the outfalls, thermal effluents become mixed with receiving seawater, and elevated tempera- 
ture and chlorination by-products are always observed near the discharge area (Jenner et al. 1997, Allonier et al. 1999). Therefore, thermal discharges from a coastal power station have 2 main components of pollution to coastal waters, i.e. high temperature and chemicals formed during antifouling procedures.

Micro-organisms are numerically abundant in coastal waters and carry out many ecologically important roles in coastal ecosystems. Changes in microbial activities caused by changes in environmental conditions will thus confer significant impacts on functions of coastal ecosystems. In fact, marine bacterial responses to additions of inhibitory substances and organic pollutants have been extensively studied (Azam et al. 1977, Siebers et al. 1981, Hudak \& Fuhrman 1988, Riemann \& Lindgaard-Jørgensen 1990). Responses of marine bacteria and heterotrophic nanoflagellates (HNF) to temperature changes have also been studied in detail (Marrasé et al. 1992, Shiah \& Ducklow 1994). Thus, if thermal effluents have deleterious effects on natural marine microbes, they should be easily detected. Some studies have examined effects of chlorination on marine natural phytoplankton (Carpenter et al. 1972, Eppley et al. 1976). However, studies on effects of thermal effluents on both natural marine bacteria and HNF using ecologically quantitative approaches are rare. To compare bacterial activities, earlier studies either used the heterotrophic potential approach to calculate maximum uptake velocity ( $\left.V_{\max }\right)$ (Davis \& Coughlan 1978) or measured uptake rates of ${ }^{3} \mathrm{H}$-glucose added as a tracer (Larrick et al. 1981). However, these approaches do not quantitatively assess the bacterial utilization of organic matter or in situ growth rates of bacteria in the sea (Azam \& Fuhrman 1984). Further, $V_{\max }$ has been shown to increase gradually as the range of added glucose concentration is increased (Azam \& Hodson 1981). Plate counts have also been used to determine the effect of thermal effluents on bacteria (Solski 1974, Guthrie et al. 1978). It is now known that plate count approaches grossly underestimate total bacteria, total viable bacteria or bacterial diversity in samples (Ferguson et al. 1984, Giovannoni \& Rappé 2000). Thus, global effects of thermal effluents on marine bacteria occurring naturally might not have been accurately measured. Based on earlier studies, however, Langford (1990) concluded that short-term temperature exposure had little effect on bacteria over the range normally found in thermal discharges and that the total effects of a thermal discharge would mainly depend on the concentrations of chlorine residuals present.

The goals of the present study were to assess the effects of thermal discharge on coastal bacteria and HNF using well-established, quantitative, microbial ecological techniques and to confirm the conclusions of
Langford (1990). To analyze effects of the thermal effluent on coastal bacteria and HNF, we measured bacterial abundance and production, HNF abundance and grazing rates on bacteria along with environmental parameters in coastal waters around a coastal power station. We also carried out manipulation and dilution experiments to evaluate the effects of thermal effluents on coastal bacteria and HNF.

\section{MATERIALS AND METHODS}

A coastal power station at Hadong. Hadong Power Station is located between Stn I (intake) and D (discharge) in a coastal area of Kwang-yang Bay, Korea (Fig. 1). The inlet for intake of seawater is located at $10 \mathrm{~m}$ depth, and thermal effluents are discharged to the receiving seawater at the outlet. At present, 4 power plants are operating, and a direct cooling system is employed. The time taken for the cooling water to travel between the dosing point and the outfall is ca $20 \mathrm{~min}$. To prevent growth of biofilms on the surface of condenser tubes, sodium hypochlorite produced from electrolysing of seawater is applied continuously. The initial dose of sodium hypochlorite is ca $0.35 \mathrm{ppm}$ chlorine. However, the residual chlorine concentration of seawater in the undiluted effluent stream is kept at ca 0.05 to $0.10 \mathrm{ppm}$. No significant difference was found in $\mathrm{pH}$ between intake and outlet areas (Huh 2000).

Study area and sample collection. During 4 investigations in November 1998 and July, August and November 1999 in the Hadong area (Fig. 1), seawater samples were collected with 51 Niskin bottles from 0,3 and $5 \mathrm{~m}$ depth. Stn D was located at the center of the outlet, which was connected to an adjacent coastal area. At this station, surface seawater samples were collected with a clean 11 polycarbonate bottle. Each sample was used for determining chlorophyll a ( $\mathrm{chl} a$ ), HNF abundance, HNF grazing rates on bacteria and bacterial abundance and production.

Bacterial abundance and production. Samples for measurements of bacterial abundance were fixed with $0.2 \mu \mathrm{m}$ filtered, borate-buffered formalin (final conc. of $2 \%)$. Bacteria, stained with DAPI $\left(4^{\prime}, 6^{\prime}\right.$-diamidino-2phenylindole) and collected on black $0.2 \mu \mathrm{m}$ polycarbonate filters, were counted under UV excitation using an epifluorescence microscope (Porter \& Feig 1980). Bacterial production was measured by the ${ }^{3} \mathrm{H}$-thymidine and ${ }^{14} \mathrm{C}$-leucine incorporation method (Ducklow et al. 1992). Ten milliliter samples, in triplicate, were filled into sterile polypropylene tubes, and both ${ }^{3} \mathrm{H}$-thymidine (specific activity $=84 \mathrm{Ci} \mathrm{mmol}^{-1}$ ) and ${ }^{14} \mathrm{C}$-leucine (specific activity $=315 \mathrm{mCi} \mathrm{mmol}^{-1}$ ) were added to the tubes, each at $10 \mathrm{nM}$ (final conc.). All the tubes were incubated in the 
dark for 0.5 to $1 \mathrm{~h}$ at in situ water temperature. Formalin-killed samples (final conc. of $2 \%$ ) served as blanks. After incubation, ${ }^{3} \mathrm{H}$-thymidine and ${ }^{14} \mathrm{C}$-leucine incorporation was stopped by adding $2 \%$ formalin. The samples were filtered onto $0.2 \mu \mathrm{m}$ cellulose nitrate filters (Whatman) and rinsed according to Ducklow et al. (1992). The filters were radio-assayed. The incorporated radioactivity was converted to cell number produced using a conversion factor of $2.65 \times 10^{18}$ cells $\mathrm{mol}^{-1}$ thymidine incorporated and $0.18 \times$ $10^{18}$ cells $\mathrm{mol}^{-1}$ leucine incorporated (Ducklow et al. 1992).

HNF abundance and grazing rates of HNF. Samples for measurements of HNF abundance were fixed immediately with alkaline Lugol solution (final conc. of $0.5 \%$ ) and borate-buffered formalin (final conc. of $3 \%$, Sherr et al. 1989). Primulin-stained HNF collected on $0.4 \mu \mathrm{m}$ polycarbonate filters $(25 \mathrm{~mm}$

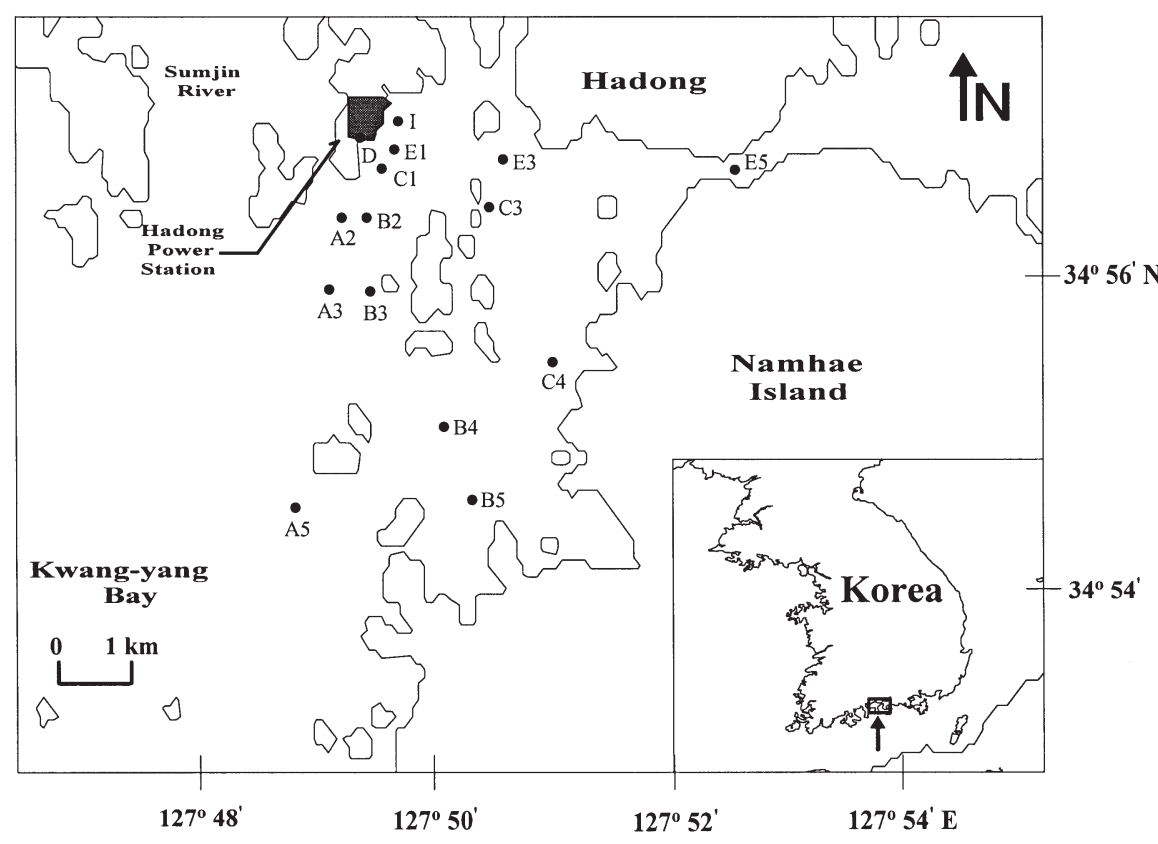

Fig. 1. Study area and sampling stations in Kwang-yang Bay, Korea diameter) were enumerated with UV excitation using an epifluorescence microscope (Caron 1983). HNF grazing rates on bacteria were measured by using fluorescently labeled bacteria (FLB) prepared according to Sherr et al. (1987). For detailed descriptions, see Cho et al. (2000). Briefly, FLB were prepared by staining natural bacterial samples collected from coastal waters with 5-(4,6-dichlorotriazin-2-yl) aminofluorescein (DTAF). The added concentration of FLB was from 4 to $14 \%$ of the bacterial abundance. Grazing experiments were conducted in the dark at in situ temperature. Subsamples of $30 \mathrm{ml}$ were collected at 0,10,20 and $30 \mathrm{~min}$, fixed and kept refrigerated until microscopic examinations. Subsamples were primulin-stained and filtered, and at least 150 microscopic fields were counted. Bacterivory rates were measured over the linear portion of the uptake curve. The ranges for the coefficient of variation (i.e. $100 \times \mathrm{SD}$ over the mean) of the slopes from duplicate bottles were from 2 to $40 \%$ (mean \pm SD: $13.7 \pm 9.2 \%$ ). Grazing rates were calculated by multiplying the ratio of bacterial abundance to FLB by the mean values of ingested FLB $\left(\mathrm{l}^{-1} \mathrm{~h}^{-1}\right)$.

Manipulation and dilution experiments. We carried out manipulation and dilution experiments to assess the short-term toxic effects of thermal effluents on bacteria and HNF in coastal waters. In the first manipulation experiment, using intake seawater, we assessed influences of temperature and chlorine (added as sodium hypochlorite) on coastal microbes: (1) $0.5 \mathrm{ppm}$ (final conc.) of chlorine was added to 2 polycarbonate bottles, which were incubated at in situ temperature;

(2) addition of $0.5 \mathrm{ppm}$ (final conc.) of chlorine and increase of water temperature to $40 \pm 1^{\circ} \mathrm{C}$ were applied in 2 other bottles; (3) water temperature was increased to $40 \pm 1^{\circ} \mathrm{C}$ in the remaining 2 bottles. Another 2 bottles were employed as controls and incubated at in situ temperature. Before the treatments, 4 bottles were pre-incubated for ca $40 \mathrm{~min}$ at $40^{\circ} \mathrm{C}$, the temperature inside the cooling system. Incubations of samples lasted $2 \mathrm{~h}$, and subsampling was carried out every hour. In a second series of experiments, we only focused on influences of varying concentrations of chlorine on coastal bacteria and HNF. We added varying concentrations $(0.13,0.25$ and $0.5 \mathrm{ppm}$ chlorine equivalent) of sodium hypochlorite to coastal seawater samples and incubated samples for $2 \mathrm{~h}$ at ambient temperature. Subsamples were collected every hour for measurements of bacterial abundance and production and HNF abundance. In dilution experiments, the effluents were cooled to near in situ coastal water temperature and then diluted with coastal seawater 2(or 5-), 10-, and 100-fold. After $30 \mathrm{~min}$ incubations of coastal waters, the effluents and variously diluted effluents, samples were collected for measurements of microbial variables.

Other analyses. Water temperature was measured with a digital thermometer (APPA Technology Co.). Salinity was measured with a temperature-salinity bridge (YSI 30). Samples for chl a measurements were filtered on GF/F (Whatman) filters. The filters were kept at $-20^{\circ} \mathrm{C}$ and brought to the laboratory. Concen- 
trations of chl a were measured spectrophotometrically according to Parsons et al. (1984). Concentrations of residual free-chlorine were measured directly at the sampling points using a portable photometer (YSI 9600) and the recommended tablets (Palintest Ltd, Catalogue
No. YAP 021 containing DPD (diethyl-p-phenylene diamine)). The tablets were added to seawater samples, and a pink color developed as a result of a reaction. Linear regression and $t$-tests were performed using SPSS for Windows (SPSS Inc. Version 8.0).

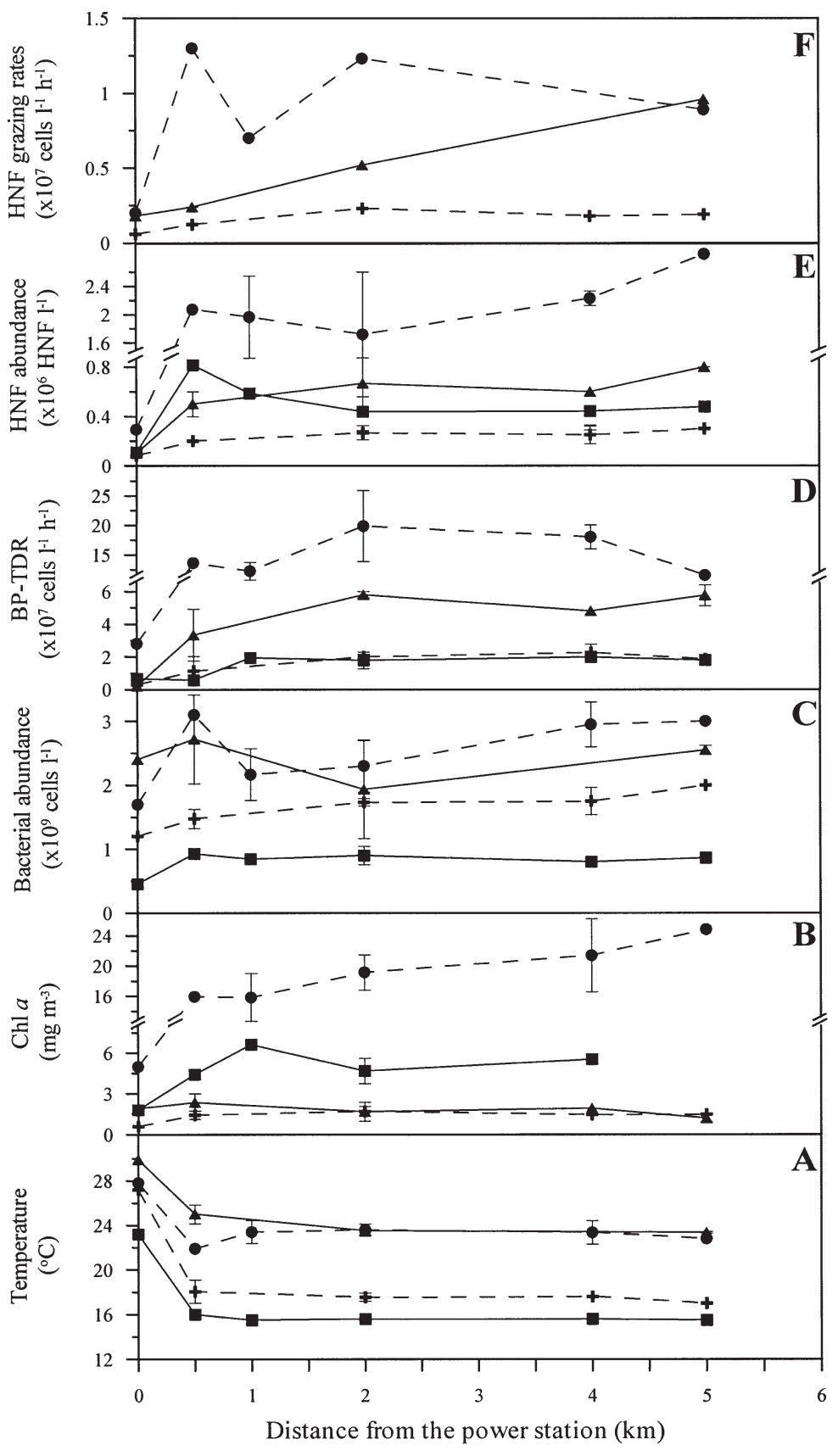

Fig. 2. (A) Temperature, (B) chlorophyll a ( $\operatorname{chl} a)$, and (C, D) bacterial and $(\mathrm{E}, \mathrm{F})$ heterotrophic nanoflagellate (HNF) variables vs distance from the power station (BP-TDR, bacterial production based on thymidine incorporation). Mean $\pm 1 \mathrm{SD}$ of data are shown for stations at the same distance. When error bars are not shown, 1 SD is less than the size of the symbol. Different symbols represent different investigation dates: (-) November 1998, $(\bullet$ July, (₫) August, and (+) November 1999

\section{RESULTS}

\section{Surface distributions of temperature, chl $a$, bacterial and HNF variables, and residual chlorine}

Only data from surface waters were presented here, because data from the surface more clearly showed the patterns of influences of thermal discharges than those from subsurface waters. Surface water temperature at the outlet was between 27.8 and $29.9^{\circ} \mathrm{C}$ in summer and between 23.2 and $27.2^{\circ} \mathrm{C}$ in November, and always from 5 to $10^{\circ} \mathrm{C}$ higher at the outlet (i.e. Stn D) than at any other station (Fig. 2A). Surface water temperature was, however, almost uniform within distances of 1 to $5 \mathrm{~km}$ from the power station throughout the investigations. Chl a concentrations were always low at Stn D, but increased with distance (Fig. 2B), except in August 1999. Bacterial abundance was also lower at Stn D than at other stations, except in August 1999 (Fig. 2C). Bacterial production was always lower at Stn D, and increased with distance (Fig. 2D). Both HNF abundance and HNF grazing rates on bacteria were always lower at Stn D than at other stations and increased with distance (Fig. 2E,F). The increase of bacterial production, HNF abundance and HNF grazing rates with distance from the power station was more pronounced in summer than in winter (Fig. 2D-F). Concentrations of residual chlorine were below 0.03 ppm in coastal waters including Stn D during this study (data not shown), with the exception of 1 sample that had $0.05 \mathrm{ppm}$ (in August 1999 at the surface at Stn C2).

\section{Microbial ecological interrelationships}

In a temperature vs salinity diagram (Fig. 3A), it was obvious that data from Stn D distributed separately from the remaining data, due to the high temperature there. When data from Stn D were 
excluded, some interrelationships improved very significantly (Fig. 3B-D), illustrating the negative effects of the effluents on the corresponding microbial variables (i.e. low bacterial abundance and production and HNF abundance). The remaining interrelationships (Fig. 3E-H) showed trends typical of coastal waters, regardless of inclusion of Stn D data; bacterial cell production increased with increases in chl a (Fig. 3E), and bacterial protein synthesis rates were tightly coupled with DNA synthesis rates (Fig. 3F). HNF abundance and grazing rates increased with increases in bacterial cell production (Fig. 3G,H).

\section{Manipulation and dilution experiments}

One of the typical results is shown (Fig. 4A), in which increased temperature $\left(40^{\circ} \mathrm{C}\right)$ and/or hypochlorite addition were applied to nearshore waters. Increased temperature had somewhat inhibitory effects on bacterial abundance and bacterial production. After $1 \mathrm{~h}$ of exposure to $40^{\circ} \mathrm{C}$, bacterial abundance decreased substantially $(21 \%$ reduction) compared to the control and was still lower after $2 \mathrm{~h}$ of incubation. Bacterial protein synthesis rate, after $2 \mathrm{~h}$ of exposure to $40^{\circ} \mathrm{C}$, was $61 \%$ of the control value. Additions of hypochlorite (giving $0.5 \mathrm{ppm}$ chlorine equivalent) caused almost complete inhibition of bacterial production. Addition of $0.5 \mathrm{ppm}$ chlorine as hypochlorite also caused a ca $50 \%$ decrease in bacterial abundance. But, an addition of $0.13 \mathrm{ppm}$ chlorine as hypochlorite did not cause any change in bacterial abundance (see Fig. 4B). Double treatments of high temperature and chlorine $(0.5 \mathrm{ppm})$ caused similar decreases in bacterial abundance and production as chlorine $(0.5 \mathrm{ppm})$. Thus, the results indicate that effects of low levels of chlorine are dominant over the effects of high temperature $\left(40^{\circ} \mathrm{C}\right)$. Interestingly, high temperature had no inhibitory effect on HNF abundance. After $2 \mathrm{~h}$ of incubation, HNF abundance, in contrast, increased significantly $(24 \%$ increase compared to control). After $2 \mathrm{~h}$ of hypochlorite additions, HNF abun- dance significantly decreased to $31 \%$ of the control. Combined effects of high temperature and chlorine $(0.5 \mathrm{ppm})$ were statistically similar $(\mathrm{p}>0.05)$ to the chlorine effect on HNF abundance during the $2 \mathrm{~h}$ of incubation, suggesting no synergistic effect of high temperature and chlorine on HNF. Overall, these results
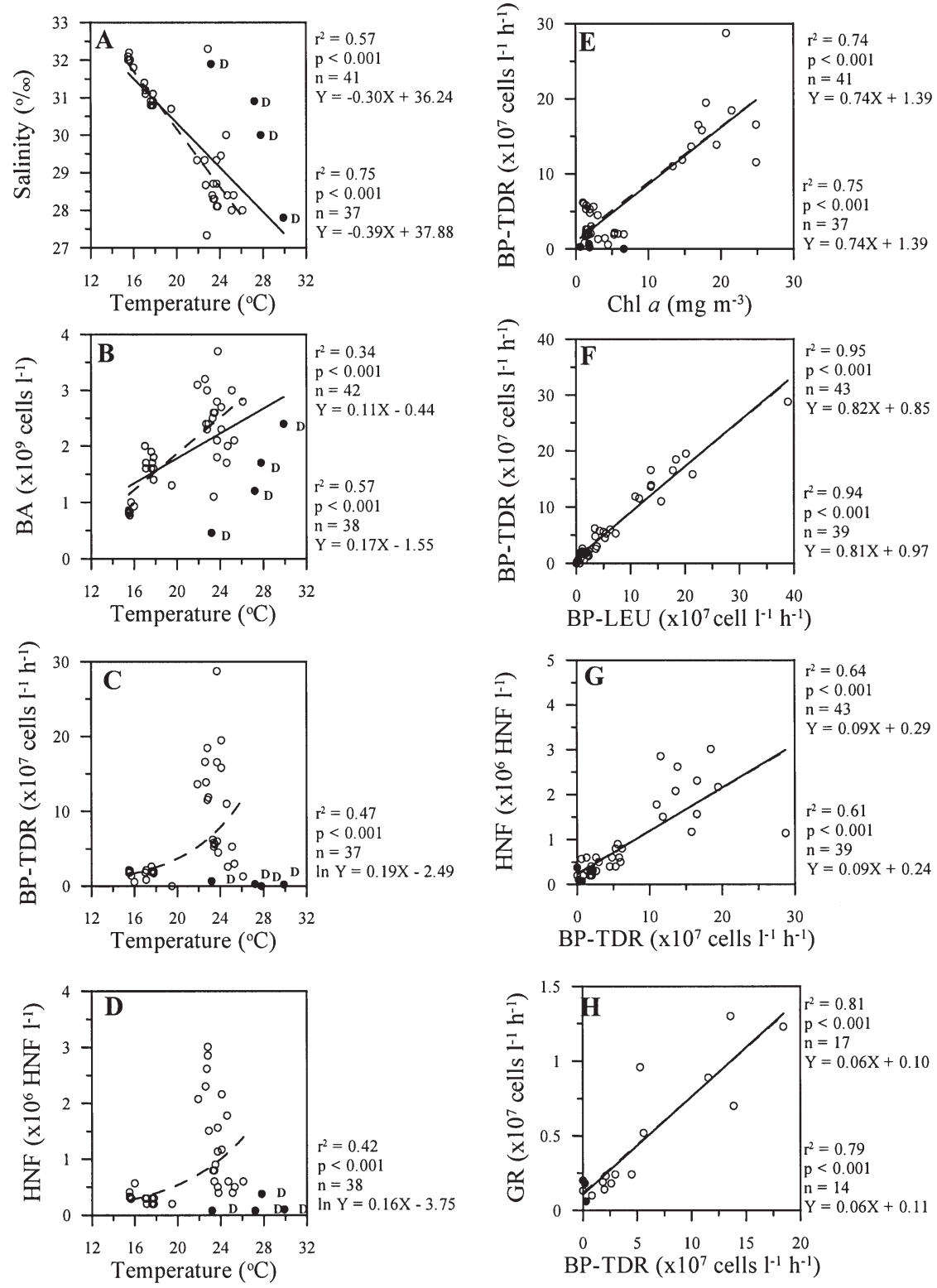

Fig. 3. Interrelationships between temperature and (A) salinity, (B) bacterial abundance (BA), (C) bacterial production based on thymidine incorporation (BP-TDR) and (D) heterotrophic nanoflagellate (HNF) abundance; between chlorophyll $a(\mathrm{chl} \mathrm{a})$ and BP-TDR (E); between bacterial production based on leucine incorporation (BP-LEU) and BP-TDR $(\mathrm{F})$; between BP-TDR and HNF abundance $(\mathrm{G})$; and between BP-TDR and HNF grazing rates (GR) (H). D: data from discharge-channel. Solid and dashed lines: regression lines for all data and data without outlet, respectively (the statistics and equations for solid and dashed lines are shown at the top and bottom, respectively, on the right side of each panel) 
(A)
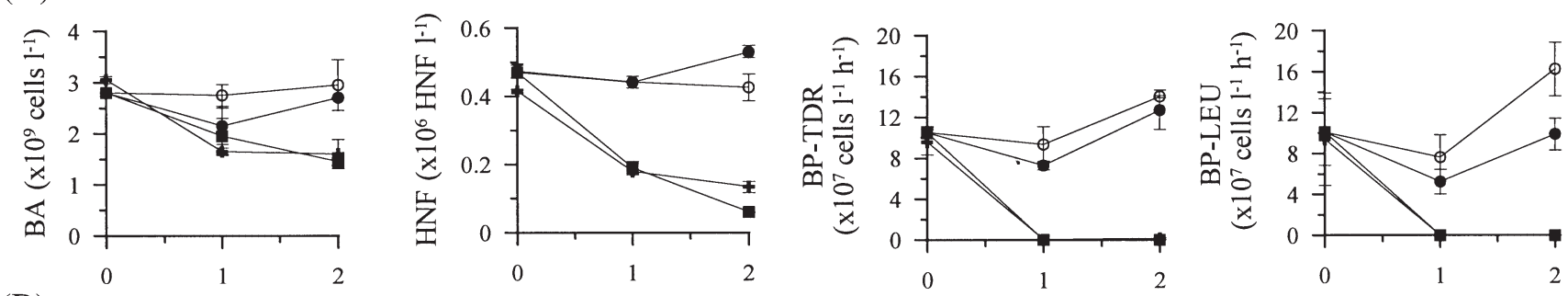

(B)
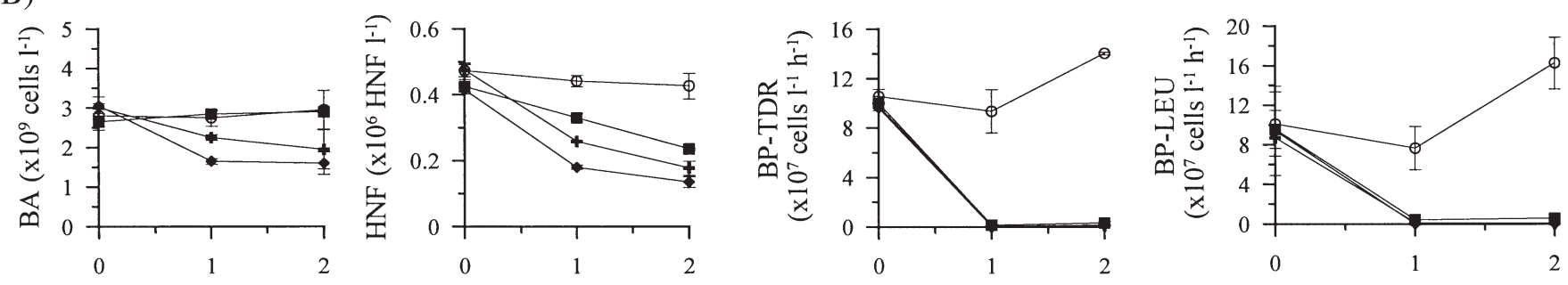

Incubation time $(\mathrm{h})$

Fig. 4. (A) Effects of increased temperature $\left(40^{\circ} \mathrm{C}\right)$ and hypochlorite on microbial variables. Different symbols represent different treatments: $(\circ)$ control, $(+)$ addition of $0.5 \mathrm{ppm}$ chlorine as hypochlorite, $(\bullet)$ increased temperature, $(\bullet)$ increased temperature and addition of $0.5 \mathrm{ppm}$ chlorine. (B) Effects of different concentrations of chlorine added as hypochlorite on microbial variables. Dif-

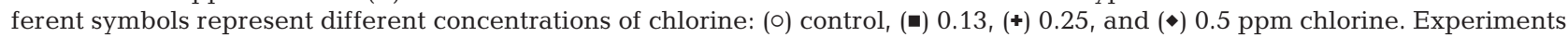
were done in August 1999. Error bars represent 1 SD. When error bars are not shown, 1 SD is less than the size of the symbol

suggest that the effect of chlorine would be more dominant during a short-term period than that of high temperature to coastal bacteria and HNF in the study area.

In other experiments, various concentrations of chlorine were added to seawater (Fig. 4B). It was clearly shown that a chlorine concentration as low as $0.13 \mathrm{ppm}$ almost completely inhibited bacterial cell production and protein production activities. Decreases in bacterial and HNF abundances were detected at concentrations $>0.13 \mathrm{ppm}$ chlorine after $1 \mathrm{~h}$ of incubation.

We further tested the effects of thermal effluents by diluting discharged waters with nearshore waters (Fig. 5). In one experiment (Fig. 5A) in which outlet water was used, bacterial production showed some- what lower values than those expected from mixing of the nearshore waters and effluents. In another experiment, in which condenser water was used (Fig. 5B), the effluent showed no inhibitory effect on bacterial abundance at 10- and 100-fold dilutions, similar to the first experiment, but there were significant inhibitory effects on bacterial production, HNF grazing rates and HNF abundance. The inhibitory effects were the greatest at the lowest dilution. Although drastic decreases in bacterial production were observed in both outlet and condenser waters, substantial amounts (4 to $21 \%$ of bacterial production found in inlet seawater) of bacterial production were observed (Fig. 5).

Table 1. Comparisons of measured (Meas) and estimated (Est) values of bacterial production, HNF (heterotrophic nanoflagellate) abundance and grazing rate at the outlet. Dilution factor of condenser water $(F)$ with receiving seawater at the outlet was calculated on the basis of water temperatures at the outlet, coastal waters (within $2 \mathrm{~km}$ from the outlet), and condenser tubes. Estimated value equals (average value for the coastal waters) $\times[(F-1) / F]$, assuming that microbial variables in condenser water were zero. nd: not detected; - : not determined

\begin{tabular}{|c|c|c|c|c|c|c|c|c|c|c|c|c|c|}
\hline \multirow[t]{2}{*}{ Date } & \multirow[t]{2}{*}{$\begin{array}{l}\text { Dilution } \\
\text { factor } \\
\text { at outlet }\end{array}$} & \multicolumn{3}{|c|}{$\begin{array}{c}\text { Bacterial production- } \\
\text { TdR } \\
\left(\times 10^{7} \text { cells l}^{-1} \mathrm{~h}^{-1}\right)\end{array}$} & \multicolumn{3}{|c|}{$\begin{array}{l}\text { Bacterial production- } \\
\text { Leu } \\
\left(\times 10^{7} \text { cells } \mathrm{l}^{-1} \mathrm{~h}^{-1}\right)\end{array}$} & \multicolumn{3}{|c|}{$\begin{array}{c}\text { HNF } \\
\text { abundance } \\
\left(\times 10^{6} \mathrm{HNF} \mathrm{l}^{-1}\right)\end{array}$} & \multicolumn{3}{|c|}{$\begin{array}{c}\text { HNF } \\
\text { grazing rates } \\
\left(\times 10^{7} \text { cells } \mathrm{l}^{-1} \mathrm{~h}^{-1}\right)\end{array}$} \\
\hline & & Meas & Est & $\frac{\text { Meas }}{\text { Est }}$ & Meas & Est & $\frac{\text { Meas }}{\text { Est }}$ & Meas & Est & $\frac{\text { Meas }}{\text { Est }}$ & Meas & Est & $\frac{\text { Meas }}{\text { Est }}$ \\
\hline Nov 1998 & 3.20 & 0.66 & 1.26 & 0.52 & 0.34 & 1.44 & 0.23 & 0.08 & 0.23 & 0.33 & - & - & - \\
\hline Jul 1999 & 3.82 & nd & 12.09 & - & nd & 14.63 & - & 0.38 & 1.30 & 0.29 & 0.20 & 0.74 & 0.27 \\
\hline Aug 1999 & 3.20 & 0.20 & 2.10 & 0.10 & 0.02 & 2.92 & 0.01 & 0.10 & 0.36 & 0.28 & 0.18 & 0.16 & 1.09 \\
\hline Nov 1999 & 2.45 & 0.29 & 0.73 & 0.39 & 0.09 & 0.65 & 0.13 & 0.08 & 0.12 & 0.68 & 0.06 & 0.07 & 0.78 \\
\hline
\end{tabular}




\section{DISCUSSION}

Analyses of horizontal distributions of microbiological variables, interrelationships between microbiological variables and temperature, and manipulation and dilution experiments gave consistently similar results: thermal effluents seemed to have inhibitory effects on bacterial production and on HNF grazing rates and abundance. Treatments of full-load chlorination and high temperature in the cooling system seemed to be highly effective in reducing activities and abundances of natural marine bacteria and HNF. Further, our results suggest that inhibitory effects are overwhelmingly due to chlorination and not to thermal loading of the effluents.

A noteworthy observation of this study was that bacterial and HNF activities were significantly inhibited on diluting the effluents with intake seawater 10- to 100-fold. Since such dilutions of the effluents with intake seawater $(<0.03 \mathrm{ppm}$ chlorine) will lower the chlorine concentration below 0.03 ppm, which is the natural background level (Eppley et al. 1976), no inhibitory effects on micro-organisms would occur. Thus, the inhibitory effects of the effluents on bacteria and HNF at such dilutions strongly suggest the presence of inhibitory substances (e.g. chlorination by-products) formed during the chlorination process in the effluents.

The presence of inhibitory chlorination by-products in the thermal effluents also helps explain the strikingly low values of bacterial production and HNF grazing and abundance in the outlet, where the residual chlorine concentration was already at natural background levels. Mixing of the thermal effluent with receiving seawater at the outlet is calculated to bring a $3.2 \pm 0.6$-fold dilution of the effluent, based on temperature data from the outlet, coastal seawater and condenser tubes. If chlorination treatments were assumed to have a completely lethal effect on marine microbes in the effluents and dilution of the effluents with receiving water did not cause any effect on micro-organisms, ca $2 / 3$ of the values for microbial variables of the coastal waters were expected to be found at the outlet (this might be a conservative estimate). If some bacteria and HNF survived during the chlorination treatment (see Fig. 5), the val-
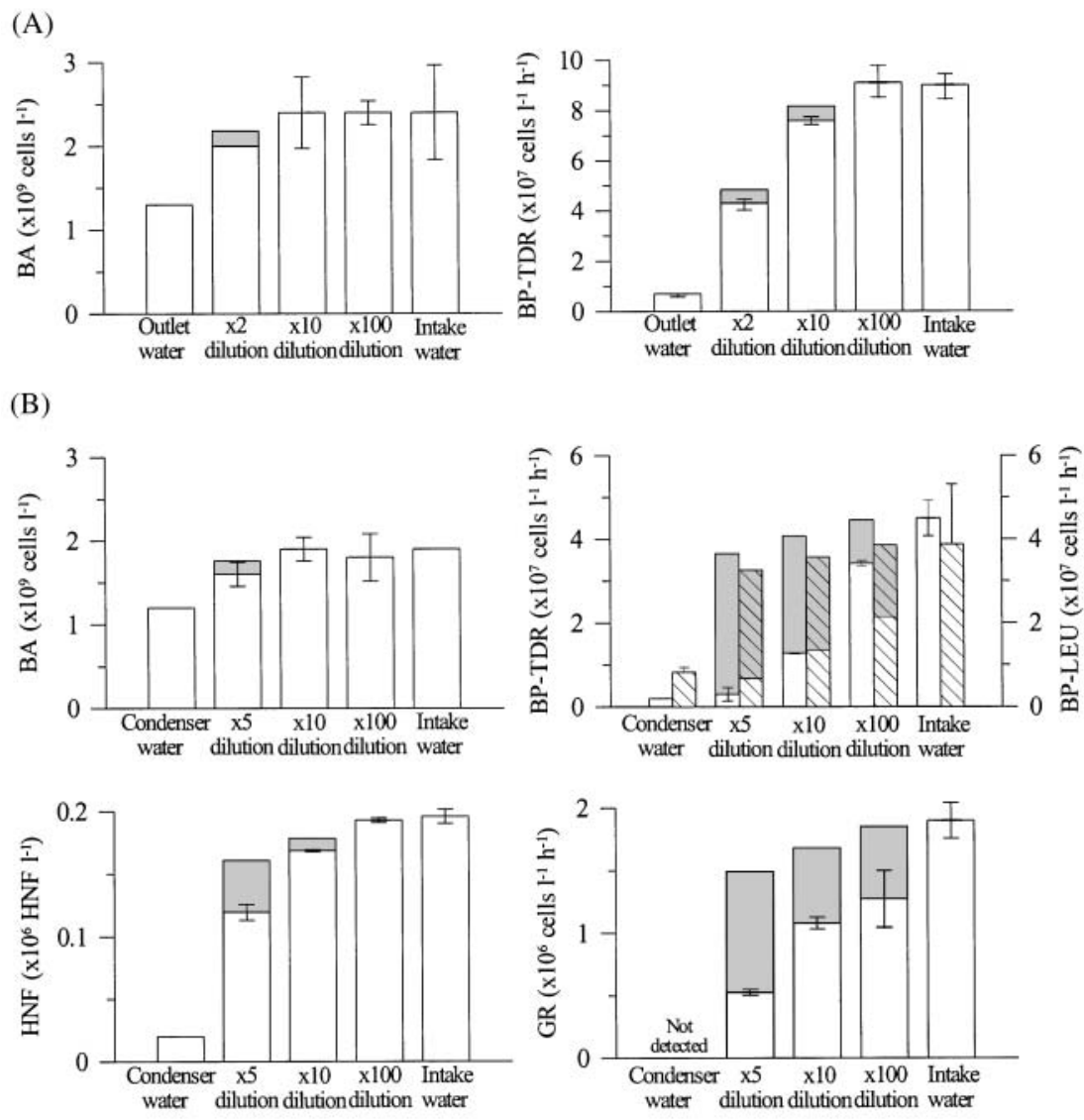

Fig. 5. Dilution experiments. (A) Discharged waters from outlet or (B) freshly discharged waters from condenser tubes were diluted in different ratios, with out shading) and predicted values (total height of bars) when 2 types of waters ( tion, respectively; HNF: heterotrophic nanoflagellate; GR: HNF grazing rate. Experiments A and B were done in August and November 1999, respectively. Error bars represent $1 \mathrm{SD}$. When error bars are not shown, $1 \mathrm{SD}$ is less than the size of the symbol

ues would be somewhat higher. In reality, measured values were much lower than the expected ones (Table 1): bacterial cell production and protein production was on average $34 \pm 22 \%$ and $12 \pm 11 \%$ of the expected values, respectively (Table 1 ). HNF abundance and grazing rate was, on average, $41 \pm 23 \%$ and $71 \pm$ $41 \%$ of the expected values, respectively. If the positive effects on metabollism of temperature increases at the outlet are considered, the estimated values would be much higher than those in Table 1. Therefore, the ratios of measured to estimated values could be much lower than those in Table 1. This implies that inhibitory substances (i.e. presumably chlorination by-products) formed during the chlorination process were present in the thermal discharges and further inhibited bacterial and HNF activities in the outlet. Interestingly, the in- 
hibitory effects were apparently more pronounced in summer than in winter (Table 1), although our data were limited. Consistently, formations of halogenated compound in the discharge area are known to be higher in summer than in winter (Allonier et al. 1999), probably related to the nature of the organic matter in the seawater.

In seawater, humic substances, constituting substantial fractions of dissolved organic matter (Thurman 1985), could serve as precursors of toxic organo-halogenated compounds produced during chlorination in seawater. Chlorination by-products are detected from the thermal effluents of coastal nuclear power stations in which low-level chlorination was routinely used. Bromoform, dibromoacetic acid and dibromoacetonitrile are the main compounds (Allonier et al. 1999). Further, the bromoform concentration in the plume of a coastal power plant was measurable $\left(0.26 \mu \mathrm{g} \mathrm{l}^{-1}\right)$ at a distance of 1.5 to $15 \mathrm{~km}$ from the outlet of thermal effluents, although concentration of residual oxidants was below $0.03 \mathrm{ppm}$ in the field (Jenner et al. 1997). Chlorinated humic substances from diverse sources are known to genetically mutate a strain of Salmonella typhimurium (Meier et al. 1987, Watt et al. 1996). As Allonier et al. (1999) suggested the possible toxicity of such compounds towards aquatic organisms, diverse halogenated compounds formed during chlorination of seawater might have induced toxic effects on bacteria and HNF or even have lethal effects in our samples.

As Langford (1990) concluded, in the cooling water system, chlorination seems to be the overwhelmingly responsible reason for the inhibitory effects. Combined treatments of chlorination and high temperature gave similar effects as chlorination treatment (Fig. 4). All the treatments of seawater with chlorination (0.13 to $0.5 \mathrm{ppm}$ ) caused drastic inhibition of bacterial production and significant reduction of $\mathrm{HNF}$ and bacterial abundances, indicating some lethal effects on bacteria and HNF (Fig. 4). Similarly, ${ }^{14} \mathrm{C}$-glucose uptake by bacteria was reported to be null when chlorination was in progress (Davis \& Coughlan 1978), indicating total suppression of bacterial activity by chlorination. Wood (1979, cited in Langford 1990) also reported that $0.1 \mathrm{mg} \mathrm{l}^{-1}$ residual chlorine caused at least $90 \%$ reductions of culturable bacterial counts. In this respect, observations of detectable bacterial production in condenser waters are interesting, suggesting the presence of chlorination-resistant bacteria, presumably derived from biofilms on walls of the cooling systems. Overall, it seems that chlorination is lethal for a fraction of the exposed natural marine bacteria and HNF in cooling water and induces injury in a large proportion of the remaining cells.

In contrast, the effects of high temperature were not as pronounced as those of chlorination. In an experi- ment where water temperature increased to $40^{\circ} \mathrm{C}$ for 1 to $2 \mathrm{~h}$ (Fig. 4A), bacterial cell production and abundance were only from 9 to $22 \%$ and 10 to $21 \%$ lower, respectively, than the control incubated at in situ temperature. High temperature seems to have no negative effect on HNF abundance at all: HNF abundance, in contrast, increased ca $24 \%$ after $2 \mathrm{~h}$ incubation compared to control. Thus, short-term $(<30 \mathrm{~min})$ exposure of coastal bacteria and HNF to $40^{\circ} \mathrm{C}$ would not seem to cause detrimental damage to bacteria (or probably HNF either) during passage through the cooling system. At the outlet, water temperature was 7 to $10^{\circ} \mathrm{C}$ and up to $5^{\circ} \mathrm{C}$ higher than ambient seawater temperature in November and in summer, respectively. Bacteria and $\mathrm{HNF}$ in the discharge area could be released from high-temperature (e.g. $40^{\circ} \mathrm{C}$ ) stress, but still be exposed to temperatures elevated above ambient coastal seawater. Although we did not test the effects of temperatures elevated 5 to $10^{\circ} \mathrm{C}$ above the in situ temperature, such temperatures may not have inhibitory effects on bacteria and HNF (Marrasé et al. 1992, Shiah \& Duckow 1994). Rather, they might have stimulating effects on microbial activities (Massana et al. 1994, Shiah \& Duckow 1994, Vaqué et al. 1994).

Were the low values of bacterial production at the outlet due to the effects of low-level chlorination on ${ }^{3} \mathrm{H}$ thymidine and ${ }^{14} \mathrm{C}$-leucine? In other words, chlorination might cause chemical transformation of the tracers so that incorporation rates of the tracers are reduced. Thus, bacterial production could be underestimated due to the lowered concentrations of tracers at the outlet and in condenser samples. We checked this possibility by adding stock solution of tracers to double-distilled water in which hyperchlorite was contained (final conc. of 0.03 and $0.1 \mathrm{ppm}$ chlorine equivalent). After $30 \mathrm{~min}$ of incubations with hyperchlorite, the stocks were added (vol. of $140 \mu \mathrm{l}$ ) to $10 \mathrm{ml}$ seawater to measure bacterial production. There were no significant differences between hyperchlorite-treated and control tracer stocks for bacterial production rate measurements (data not shown). Thus, low values of bacterial production were due to inhibitory effects of thermal effluents, not due to chemical alterations of tracers by chlorination.

So far, we have presumed that toxic effects arise mainly from chlorination and chlorination by-products. However, any inhibitory substance might yield similar results. Other possible toxic substances could be heavy metals, antifouling paint, or ash discharges (Larrick et al. 1981, Langford 1990). Distributions of total heavy metals of various elements ( $\mathrm{Fe}, \mathrm{Zn}, \mathrm{Cu}, \mathrm{Cr}, \mathrm{Pb}$ and $\mathrm{Cd}$ ) were not different among stations including the discharge channel (Huh 2000, S.-R. Yang pers. comm.). Further, Hadong Power Station does not treat the cooling system with antifouling paint or other coatings. Also, no ash effluents are discharged near the thermal 
discharges in the study area. Thus, it seems that the observed inhibitory effects of thermal effluents on coastal microbes were actually due to chlorination and chlorination by-products.

Finally, our results suggested that the range in which thermal effluents affect bacteria and HNF in receiving coastal waters might be proportional to 100 times the volume of the flux of condenser water. However, this could be a maximal estimate because of potential chlorine decay due to volatilization of chlorine, progressive chemical reactions of chlorine with seawater constituents, and the photochemical destruction of chlorine during mixing in the receiving water (Eppley et al. 1976). Depressed activities of bacteria and HNF in the affected region would slow down regeneration of nutrients and flow of energy and material through the microbial food web. Efforts in developing techniques to reduce the toxic effects of thermal effluents are increasing. Recently, with the aid of 'mussel monitor', 'pulse-chlorination' technology using short (i.e. a few minutes), intermittent chlorination has reduced the amount of chlorine by $50 \%$ compared to continuous chlorination (Jenner \& Polman 1998). As chlorination is still the most widely applied method for antifouling, pulse-chlorination would be preferable with fewer subsequent environmental effects.

In conclusion, thermal effluents had inhibitory effects on bacterial production and on HNF grazing rates on bacteria. The inhibitory effects seemed to be mostly due to chlorination of seawater and chlorination byproducts in the effluents. Our results suggest that natural marine micro-organisms seem to be sensitive to thermal pollution, and microbial ecological approaches are useful in assessing the magnitude of influences of thermal effluents on coastal microbes.

Acknowledgements. We thank Korea Electric Power Corporation (KEPCO) for their cooperation during the study. We thank Dr Jed Fuhrman for careful reading of an earlier version of our manuscript. We thank 4 anonymous reviewers for helpful comments. The present study was supported (in part) by the BK 21 Project of the Korean Government and a KEPCO project.

\section{LITERATURE CITED}

Allonier AS, Khalanski M, Camel V, Bermond A (1999) Characterization of chlorination by-products in cooling effluents of coastal nuclear power stations. Mar Pollut Bull 38: $1232-1241$

Azam F, Fuhrman JA (1984) Measurements of bacterioplankton growth in the sea and its regulation by environmental conditions. In: Hobbie JE, Williams PJleB (eds) Heterotrophic activity in the sea. Plenum Press, New York, p 179-196

Azam F, Hodson RE (1981) Multiphasic kinetics for D-glucose uptake by assemblages of natural marine bacteria. Mar Ecol Prog Ser 6:213-222
Azam F, Vaccaro RF, Gillespie PA, Moussalli EI, Hodson RE (1977) Controlled ecosystem pollution experiment: effect of mercury on enclosed water columns. II. Marine bacterioplankton. Mar Sci Commun 3:313-329

Caron DA (1983) Technique for enumeration of heterotrophic and phototrophic nanoplankton, using epifluorescence microscopy, and comparison with other procedures. Appl Environ Microbiol 46:491-498

Carpenter EJ, Peck BB, Anderson SJ (1972) Cooling water chlorination and productivity of entrained phytoplankton. Mar Biol 16:37-40

Cho BC, Na SC, Choi DH (2000) Active ingestion of fluorescently labeled bacteria by mesopelagic heterotrophic nanoflagellates in the East Sea, Korea. Mar Ecol Prog Ser 206:23-32

Davis MH, Coughlan J (1978) Response of entrained plankton to low-level chlorination at a coastal power station. In: Lanford TEL (ed) Ecological effects of thermal discharges. Elsevier Applied Science, London

Ducklow HW, Kirchman DL, Quinby HL (1992) Bacterioplankton cell growth and macromolecular synthesis in seawater cultures during the North Atlantic spring phytoplankton, May 1989. Microb Ecol 24:125-144

Eppley RW, Renger EH, Williams PM (1976) Chlorine reactions with seawater constituents and the inhibition of photosynthesis of natural marine phytoplankton. Estuar Coast Mar Sci 4:147-161

Ferguson RL, Buckley EN, Palumbo AV (1984) Response of marine bacterioplankton to differential filtration and confinement. Appl Environ Microbiol 47:49-55

Giovannoni S, Rappé M (2000) Evolution, diversity, and molecular ecology of marine prokaryotes. In: Kirchman DL (ed) Microbial ecology of the oceans. Wiley-Liss, New York, p 47-84

Guthrie RK, Cherry DS, Singleton FL, Harvey RS (1978) The effects of coal ash basin effluent and thermal loading on bacterial populations of flowing streams. Environ Pollut $17: 297-302$

Hudak JP, Fuhrman JA (1988) Effects of four organic pollutants on the growth of natural marine bacterioplankton populations. Mar Ecol Prog Ser 47:185-194

Huh SH (2000) Ecological effects of thermal discharges of Hadong Power Station. Korea Inter-University Institute of Ocean Science, Pukyong National University, Pusan (in Korean)

Jenner HA, Polman HJG (1998) Pulse-chlorination: a new way of reducing chlorine for mitigation of mussel fouling. Proc 8th Int Zebra Mussel and Other Nuisance Species Conf. The Professional Edge, Pembroke, ON (Abstract)

Jenner HA, Taylor CJL, van Donk M, Khalanski M (1997) Chlorination by-products in chlorinated cooling water of some European coastal power stations. Mar Environ Res 43:279-293

Langford TEL (1990) Ecological effects of thermal discharges. Elsevier Applied Science, London

Larrick SR, Clark JR, Cherry DS, Cairns J Jr (1981) Structural and functional changes of aquatic heterotrophic bacteria to thermal, heavy, and fly ash effluents. Water Res 15: $875-880$

Marrasé C, Lim EL, Caron DA (1992) Seasonal and daily changes in bacterivory in a coastal plankton community. Mar Ecol Prog Ser 82:281-289

Massana RC, Stumm CK, Pedrós-Alió C (1994) Effects of temperature, sulfide, and food abundance on growth and feeding of anaerobic ciliates. Appl Environ Microbiol 60: 1317-1324

Meier JR, Knohl RB, Coleman WE, Ringhand HP, Munch JW, 
Kaylor WH, Streicher RP, Kopfler FC (1987) Studies on the potent bacterial mutagen, 3-chloro-4-(dichloromethyl)-5hydroxy-2(5H)-furanone: aqueous stability, XAD recovery and analytical determination in drinking water and in chlorinated humic acid solutions. Mutat Res 189: 363-373

Parsons T, Maita Y, Lalli CM (1984) A manual of chemical and biological methods for water analysis. Pergamon Press, Oxford

Porter KG, Feig YS (1980) The use of DAPI for identifying and counting aquatic microflora. Limnol Oceanogr 25: 943-948

Riemann B, Lindgaard-Jørgensen P (1990) Effects of toxic substances on natural bacterial assemblages determined by means of $\left[{ }^{3} \mathrm{H}\right]$ thymidine incorporation. Appl Environ Microbiol 56:75-80

Sherr BF, Sherr EB, Fallon RD (1987) Use of monodispersed, fluorescently labeled bacteria to estimate in situ protozoan bacterivory. Appl Environ Microbiol 53:958-965

Sherr BF, Sherr EB, Pedrós-Alió C (1989) Simultaneous measurement of bacterioplankton production and protozoan bacterivory in estuarine water. Mar Ecol Prog Ser 54: 209-219

Editorial responsibility: Otto Kinne (Editor),

Oldendorf/Luhe, Germany
Shiah FK, Ducklow HW (1994) Temperature and substrate regulation of bacterial abundance, production and specific growth rate in Chesapeake Bay, USA. Mar Ecol Prog Ser 103:297-308

Siebers D, Hoppenheit M, Harms U (1981) Mercury influences uptake of amino acids by marine bacteria. Mar Ecol Prog Ser 6:101-113

Solski A (1974) The influence of discharged heated waters from the power station at Skawina on microflora of Vistula River. Pol Arch Hydrobiol 21:75-82

Thurman EM (1985) Organic geochemistry of natural waters. Martinus Nijhof/Dr W Junk Publishers, Dordrecht

Vaqué D, Gasol JM, Marrasé C (1994) Grazing rates on bacteria: the significance of methodology and ecological factors. Mar Ecol Prog Ser 109:263-274

Watt BE, Malcolm RL, Hayes MHB, Clark NWE, Chipman JK (1996) Chemistry and potential mutagenicity of humic substances in waters from different watersheds in Britain and Ireland. Water Res 30:1502-1516

Wood MJ (1979) The effects of passage through a power station on microorganisms entrained in estuarine cooling water. Internal Report No. RD/L/N/180/79, Central Electricity Generating Board, Leatherhead

Submitted: December 12, 2000; Accepted: August 16, 2001 Proofs received from author(s): March 4, 2002 